\title{
CALLA LILY INFLORESCENCES POSTHARVEST: PULSING WITH DIFFERENT SUCROSE CONCENTRATIONS AND STORAGE CONDITIONS ${ }^{1}$
}

\author{
Conservação pós-colheita de inflorescências de copo-de-leite: pulsing com diferentes \\ concentrações de sacarose e condições de armazenamento ${ }^{1}$
}

\author{
Elka Fabiana Aparecida Almeida², Patrícia Duarte de Oliveira Paiva ${ }^{3}$, Luiz Carlos de Oliveira Lima ${ }^{4}$, \\ Franklin Cordeiro Silva ${ }^{5}$, Juliana Fonseca ${ }^{6}$, Denismar Alves Nogueira ${ }^{7}$
}

\begin{abstract}
Calla lily is an appreciated specie used for flower arrangements. In spite of its commercial importance, there is little information on calla lily postharvest conservation. Thus, this study aimed to determine the best sucrose concentration for pulsing and cold storage conditions to extend calla lily postharvest durability. Flower stalks were submitted to a pulsing pre-treatment using 2, 4, 8, 12 and $16 \%$ sucrose in the solution, for one hour, plus a treatment with direct storage in cold chamber $\left(4^{\circ} \mathrm{C}\right)$, without a prior-treatment. Dry storage or storage in solution with the commercial product Flower $^{\circledR}$ was also tested. A completely randomized design was used with four replicates and three inflorescences per plot. Spathe length and width were daily measured from which the opening and wilting processes were analyzed. It was observed that pulsing with sucrose was efficient in extending calla lily inflorescences opening process and durability. Dry storage for short periods (less than six days) can also be used, but a prior-treatment with $12 \%$ sucrose pulsing for one hour or with a water supply for the same period was required. For storage in solution, a pulsing with $5 \%$ or $7.5 \%$ sucrose was recommended.
\end{abstract}

Index terms: Zantedeschia aethiopica, durability, floriculture.

\section{RESUMO}

Copo-de-leite é uma espécie apreciada para uso em arranjos florais. Apesar da sua importância comercial, há pouca informação sobre a conservação pós-colheita de copo-de-leite. Dessa forma, neste estudo, objetivou-se determinar a melhor concentração de sacarose para pulsing e condições de armazenamento a frio para estender a durabilidade pós-colheita de copo-de-leite. Hastes florais foram submetidas a pré-tratamento (pulsing), usando 2, 4, 8, 12 e 16\% de sacarose na solução, por 1 hora, mais um tratamento de armazenamento direto em câmara fria, sem pré-tratamento. Armazenamento a seco ou em solução com produto comercial Flower ${ }^{\circledR}$ foram também testados. Foi utilizado o delineamento experimental inteiramente casualizado com quatro repetições e três inflorescências por parcela. O comprimento e largura da espata foram medidos diariamente, sendo a partir desses, analisado o processo de abertura e senescência floral. Foi observado que o pulsing com sacarose foi eficiente para estender o processo de abertura e durabilidade de inflorescências de copo-de-leite. $\mathrm{O}$ armazenamento a seco por curto período (inferior a 6 dias) pode também ser utilizado, mas um pré-tratamento (pulsing) com $12 \%$ de sacarose por 1 hora ou manutenção em água pelo mesmo período é necessário. Para armazenamento em solução, é recomendado o pulsing com $5 \%$ ou $7,5 \%$ de sacarose.

Termos para indexação: Zantedeschia aethiopica, durabilidade, floricultura.

(Received in july 20, 2010 and approved in may 30, 2011)

\section{INTRODUCTION}

Adequate carbohydrate concentrations in the inflorescences at the time of harvest are determinant in extending vase life (MARISSEN, 2001). Carbohydrates are the main energy source necessary for the inflorescence postharvest biochemical and physiological processes (NOWAK; RUDNICKI, 1990).

Exogenous sugar supply delays senescence in inflorescences (PAULIN, 1986). Sugar acts in the maintenance of basic processes to extending the vase life of inflorescences (NOWAK; RUDNICKI, 1990). For most plants, sucrose is the main translocated sugar (TAIZ; ZEIGER, 1991) and the most used sugar for inflorescence conservation. It can be supplied in the form of pulsing, before or after storage, or even in the maintenance solution (NOWAK; RUDNICKI, 1990).

Inflorescence opening after harvest is a process that requires an energy source and complete tissue

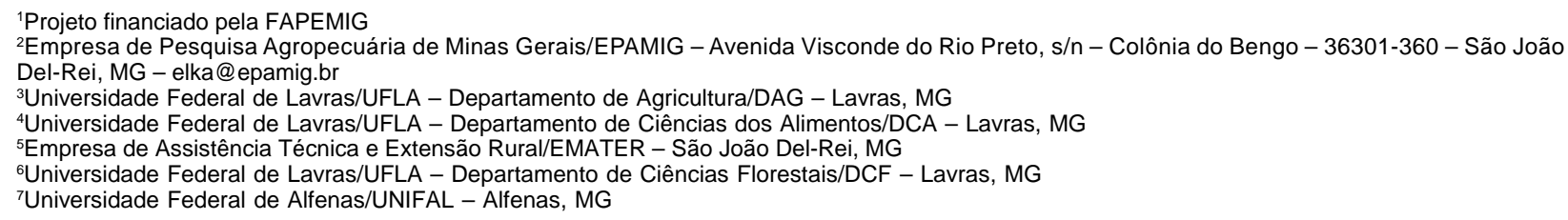


turgidity. Sucrose supply by pulsing meets these two requirements, due to the fact that it is an energy source and also its presence decreases the water potential of the inflorescence which improves water uptake by the flower stalk (KONFRANEK; HALVEY, 1976).

The most efficient sucrose concentration used to extend inflorescence vase life varies with the species. For example, for Gladiolus sp. it is recommended pulsing with 20\% sucrose solution (KONFRANEK; HALVEY, 1976), 15\% for Cyclamen sp. (HALEVY, 1984), 10\% for Consolida ajacis (FINGER, 2001), and 5\% for lily (BARBOSA et al., 2006).

Inflorescence storage in solution is the most used method, but presents the disadvantage of occupying a large space inside the cold chamber unlike the dry storage. According to Nowak e Rudnicki (1990) inflorescences stored in solution present higher durability and turgidity, although, it is possible to storage with quality calla lily in solution or in a dry system (ALMEIDA et al., 2008).

The objective of this study was to determine the best sucrose concentration for pulsing and storage conditions for calla lily to extend their postharvest durability.

\section{MATERIAL AND METHODS}

Calla lily flower stalks were harvested in the morning (7 am) and then taken to the laboratory. The harvest point was determined when the inflorescences were completely open, before the spathe tip curled down and without pollen on the spadix (NOWAK; RUDNICKI, 1990; ALMEIDA; PAIVA, 2005).

Fourteen treatments were tested resulting in a complete factorial design consisting of six postharvest procedures, two forms of storage and two additional treatments $[(6 \times 2)+2]$. A completely randomized design was used with four replications and three inflorescences per plot.

The post harvest procedures were pulsing with sucrose for one hour at concentrations of $2,4,8,12$ or $16 \%$ plus a control in pure water for the same period. After these treatment, all the flower stalks were placed inside a cold chamber $\left(4^{\circ} \mathrm{C}\right)$ in dry storage (the flower stalk bases were placed horizontally on shelves) or placed in solution with $14 \mathrm{~mL} \mathrm{~L}^{-1}$ of floral Flower ${ }^{\circledR}$ preservative.

The first additional treatment consisted of inflorescences that were taken immediately to the cold chamber after harvest without pulsing, and were stored in solution with the floral preservative Flower ${ }^{\circledR}$. In the second additional treatment, inflorescences were harvested and taken immediately to the cold chamber without pulsing, in a dry storage. Inflorescences remained for 10 days inside the cold chamber $\left(4^{\circ} \mathrm{C}\right)$, in the dark, being removed after this period and maintained at room temperature $\left(23^{\circ} \mathrm{C}\right)$ for
5 days. Daily, they were evaluated and classified by quality according criteria shown in Figure 1, and also was observed the number of days that the inflorescences remained in each class. The stalk base opening was also observed. Spathes length and width were daily measured for analysis of the opening and wilting processes.

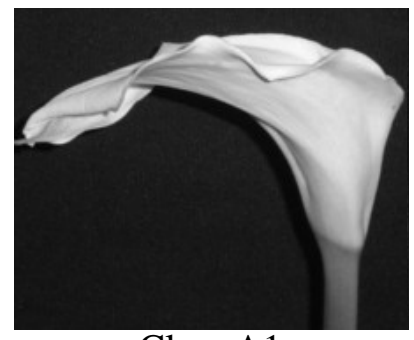

Class A1

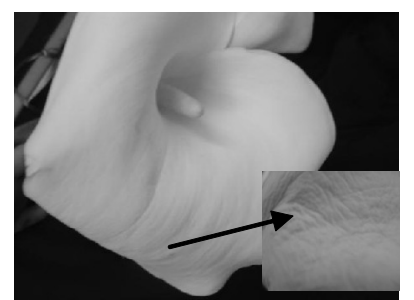

Class B (detail)

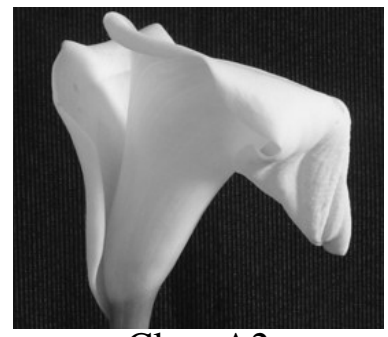

Class A2

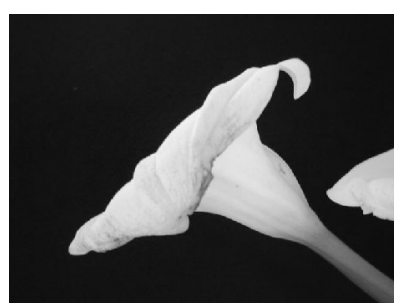

Class C
Figure 1 - Standard used to assess calla lily inflorescence quality. Class A1: turgid inflorescences, erected spathe tip, absence of wrinkles or necrosis; Class A2: turgid inflorescences, spathe tip slightly curled down, absence of wrinkles or necrosis; Class B: turgid inflorescences, spathe tip curled down, presence of wrinkles, absence of necrosis; Class C: wilted inflorescences, spathe tip curled down, presence of necrosis.

\section{RESULTS AND DISCUSSION}

\section{Results}

Inflorescences treated with sucrose pulsing or when flower stalks were placed in water before storage, presented higher durability in class A1 (8 days) and in the classes considered ideal for commercialization A1+A2 (10 days). Table 1 shows that the inflorescences from the two additional treatments (no pulsing) received this classification for a period of only 5 days (A1) and 7 days (A1+A2). Thus it is possible to consider that the prior-storage treatment of calla lily inflorescences, even with pure water only, is essential to extend their vase life, regardless of the storage system, whether dry or in solution.

Comparisons of the two additional treatments showed that the inflorescences without prior-storage 
treatment, when stored in solution, presented durability in class $\mathrm{A} 1$ for 7 days and in classes $\mathrm{A} 1+\mathrm{A} 2$ for 10 days. However, the inflorescences that were kept dry in the cold chamber remained in $\mathrm{A} 1$ and $\mathrm{A} 1+\mathrm{A} 2$ classes for only 3 days (Table 2). These inflorescences quickly lost quality due to the stress that they were submitted. Besides the lack to receive pulsing postharvest, they remained without water during storage.

Table 1 - Number of days that calla lily inflorescences remained in classes $\mathrm{A} 1$ and $\mathrm{A} 1+\mathrm{A} 2$ in function of pulsing.

\begin{tabular}{ccc}
\hline \multicolumn{3}{c}{ Number of days } \\
\hline Pulsing & Class A1 & Class A1+A2 \\
\hline Yes & $8 \mathrm{a}$ & $10 \mathrm{a}$ \\
No & $5 \mathrm{~b}$ & $7 \mathrm{~b}$ \\
\hline
\end{tabular}

Means of followed by the same letter in the column do not differ by the $\mathrm{F}$ test at $5 \%$ level probability.

Table 2 - Number of days that calla lily inflorescences remained in $\mathrm{A} 1$ and $\mathrm{A} 1+\mathrm{A} 2$ classes in function of the conservation system, without pulsing.

\begin{tabular}{ccc}
\hline Storage & Class A1 (days) & Class A1+ A2 (days) \\
\hline In solution & $7 \mathrm{a}$ & $10 \mathrm{a}$ \\
Dry & $3 \mathrm{~b}$ & $3 \mathrm{~b}$ \\
\hline
\end{tabular}

Means followed by the same letter in the column do not differ by the $\mathrm{F}$ test at $5 \%$ level of probability.

When flower stalks was stored dry, the use of $12.25 \%$ sucrose concentration for pulsing showed to be the most efficient treatment (Figure 2). Flower stalks treated with this concentration remained 11 days with $\mathrm{A} 1+\mathrm{A} 2$ classification. The inflorescences placed in solution also remained in the $\mathrm{A} 1+\mathrm{A} 2$ class for 11 days, but at a lower sucrose concentration, $5.23 \%$.

As it was observed for $\mathrm{A} 1+\mathrm{A} 2$ quality class, in $\mathrm{A} 1+\mathrm{A} 2+\mathrm{B}$ classification (total longevity), the higher sucrose concentration was more efficient for dry storage and the lower sucrose concentration resulted in greater longevity when the inflorescences were stored in solution (Figure 3). When dry storage was analyzed, the best sucrose concentration was $11.46 \%$ and the inflorescences remained at the $(\mathrm{A} 1+\mathrm{A} 2+\mathrm{B})$ commercial standard for 13 days. However, when the inflorescences were stored in solution, the use of $5.44 \%$ sucrose solution provided the greatest durability in the $\mathrm{A} 1+\mathrm{A} 2+\mathrm{B}$ classes (12 days).

Pulsing using 4, 8, 12 and $16 \%$ of sucrose solution was efficient in preventing the base of the flower stalk from opening, regardless of the conservation system, whether dry or in solution. It was also observed that flower stalks presented bases a little closed and color differences in higher concentrations (12 and 16\%), which, however showed no interference in the inflorescence quality.

It was observed during the experiment that shortly after harvest, the spathes dimensions increased, both in length and width, which characterized the inflorescence opening process.

When the inflorescences were placed in solution during storage, there was an increase in the spathe width until the eighth day (Figure 4), decreasing progressively, even when the inflorescences were removed from the cold chamber.

Inflorescences stored dry in the cold chamber presented an increase in the spathe width until the sixth day (Figure 4). After this period, the spathe width decreased until the 10th day, when the inflorescences were removed from the cold chamber and placed in receptacles with water at room temperature. The inflorescences regained their



Figure 2 - Average number of days of calla lily inflorescences remained in the A1+A2 classes as a function of the storage system (dry or in solution) and the sucrose concentrations used in pulsing. 
turgidity one day after water supply, both in the flower stalk and spathe, and consequently there was an increase in the spathe width until the 13th day decreasing again after this period. Even with turgidity recovery after placing the flower stalks in water, the inflorescences did not return to the commercial pattern presenting necrosis on the spathe. Thus it was inferred that calla lily inflorescences should not be dry stored for extended periods, with the occurrence of spathe necrosis in this situation. The indicated period for storage dry is up to six days.

Figure 5 shows that the spathe width decreased until the 11th day on inflorescences that did not receive the prior-treatment and were stored dry. This reduction resulted from the turgidity loss that was observed visually and by touching in the spathe and the flower stalk. The turgidity loss was so intense that it prevented the inflorescences to remain erect.

These inflorescences, when removed from the cold chamber $\left(4^{\circ} \mathrm{C}\right)$ and placed in receptacles with water at room temperature, re-hydrated with a progressive increase in the spathe width until the 12th day. This effect was also observed visually and through touching, observing the increase in inflorescence turgidity. After this period, the spathe width decreased again until the 15th day.

The inflorescences that had no prior-treatment and were placed in the cold chamber in solution presented continuous increase in spathe width until the seventh day of the experiment, unlike the dry stored inflorescences. After this period, the inflorescences presented progressive reduction in spathe width, even after removal from the cold chamber (Figure 5).

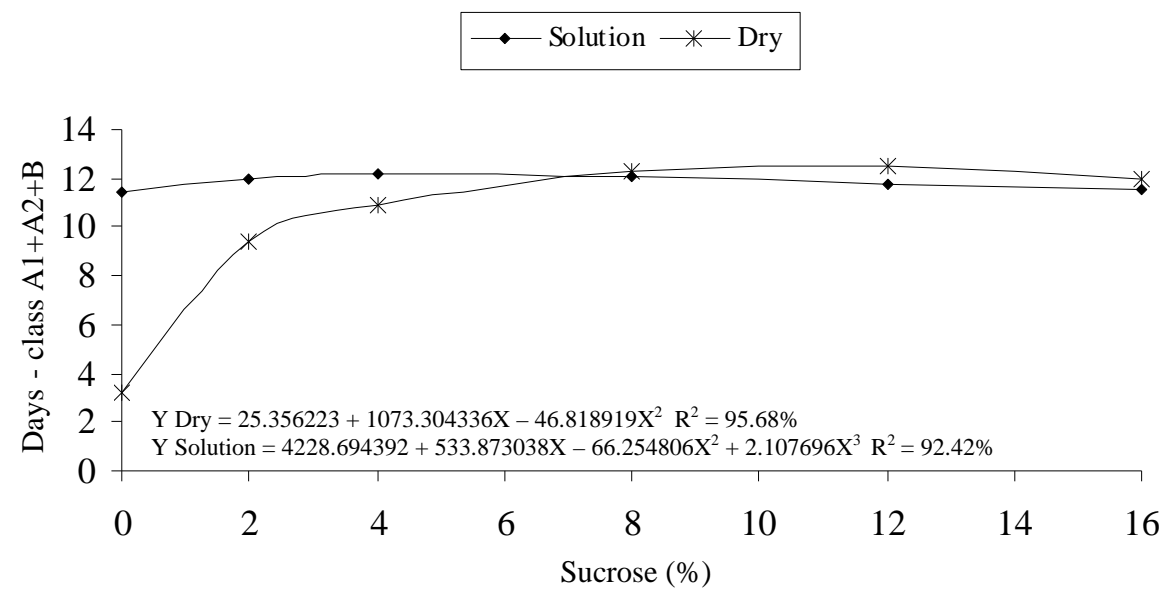

Figure 3 - Number of days of calla lily inflorescences remained at commercial standard solution as a function of the storage system (dry or in solution) and the sucrose concentrations used as pulsing.

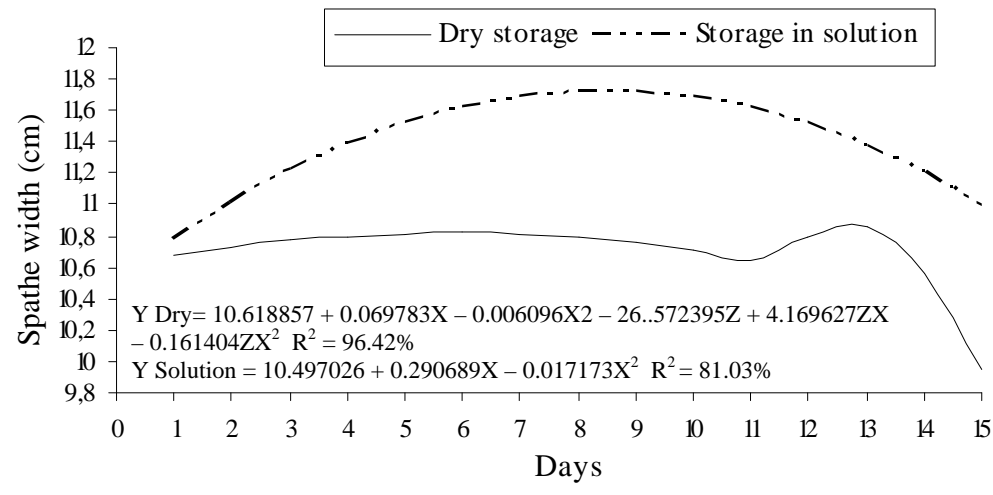

Figure 4 - Calla lily inflorescence spathe width $(\mathrm{cm})$ as a function of the conservation system (dry or in solution). 1-10 days inflorescences maintained in cold chamber at $4^{\circ} \mathrm{C} ; 11-15$ days inflorescences maintained at room temperature. 
There was a significant interaction among the procedures prior-storage and the packaging system inside the cold chamber. For the inflorescences placed in solution, $7.36 \%$ and $7.68 \%$ sucrose concentrations resulted in higher spathe width and length, respectively (Figure 6). There was no significant difference among the sucrose concentrations for spathe width and length in the inflorescences that were stored dry.

The Figure 7 shows that there was significant difference between the number of days at which the inflorescences were assessed and the conservation system used. It was observed that in the dry stored inflorescences, the spathe length decreased progressively until the 10th day of storage and, after removal from the cold chamber and placing in recipients with water. One day after water supply, an increase was observed in the calla lily spathe length in function of turgidity recovery. Further increase in spathe length was observed up to the 14 th day, but decreased after this period. The inflorescences that were placed in solution with floral preservative presented a progressive increase in spathe length.

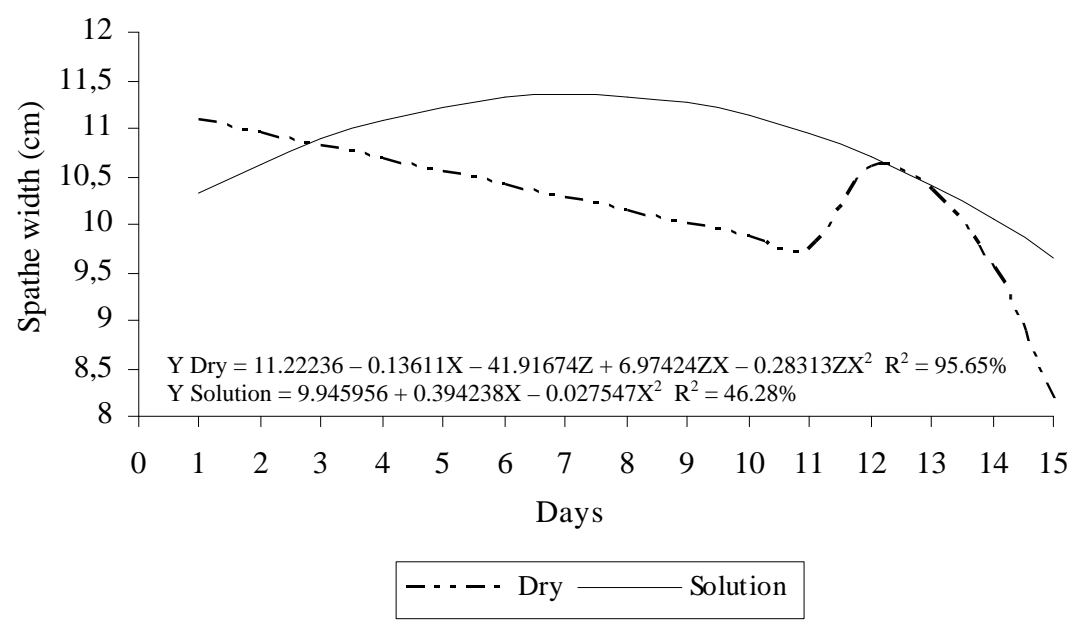

Figure 5 - Calla lily inflorescence spathe width $(\mathrm{cm})$ in function of days, for flower stalks with no pulsing and were stored dry or in solution. 1-10 days inflorescences maintained in cold chamber at $4^{\circ} \mathrm{C} ; 11-15$ days inflorescences maintained at room temperature.

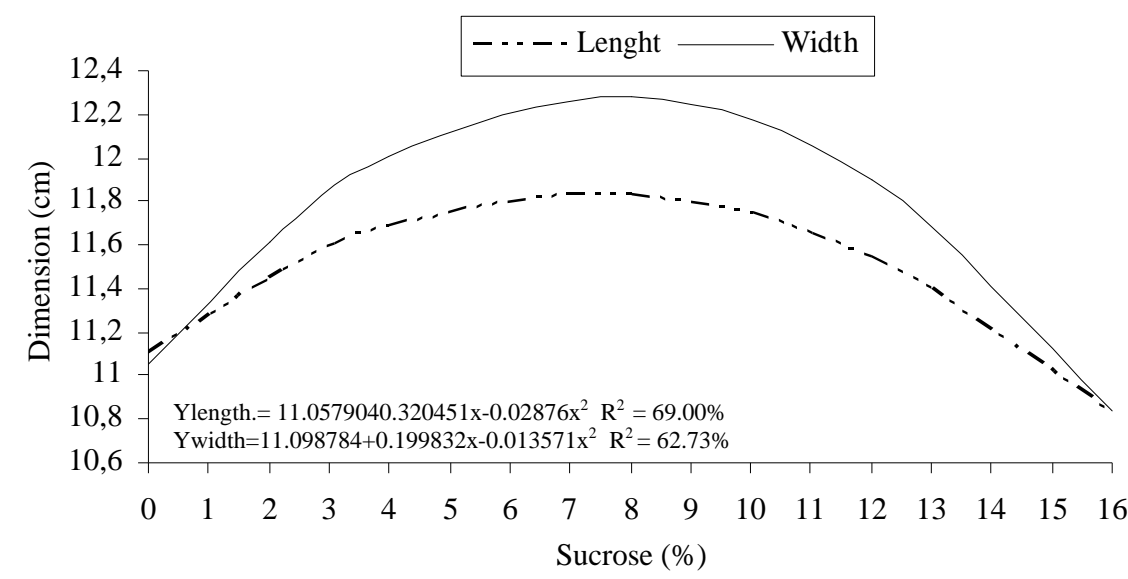

Figure 6 - Spathe length and width of calla lily inflorescences maintained in solution in a cold chamber, as a function of the sucrose concentration used in pre-storage pulsing. 


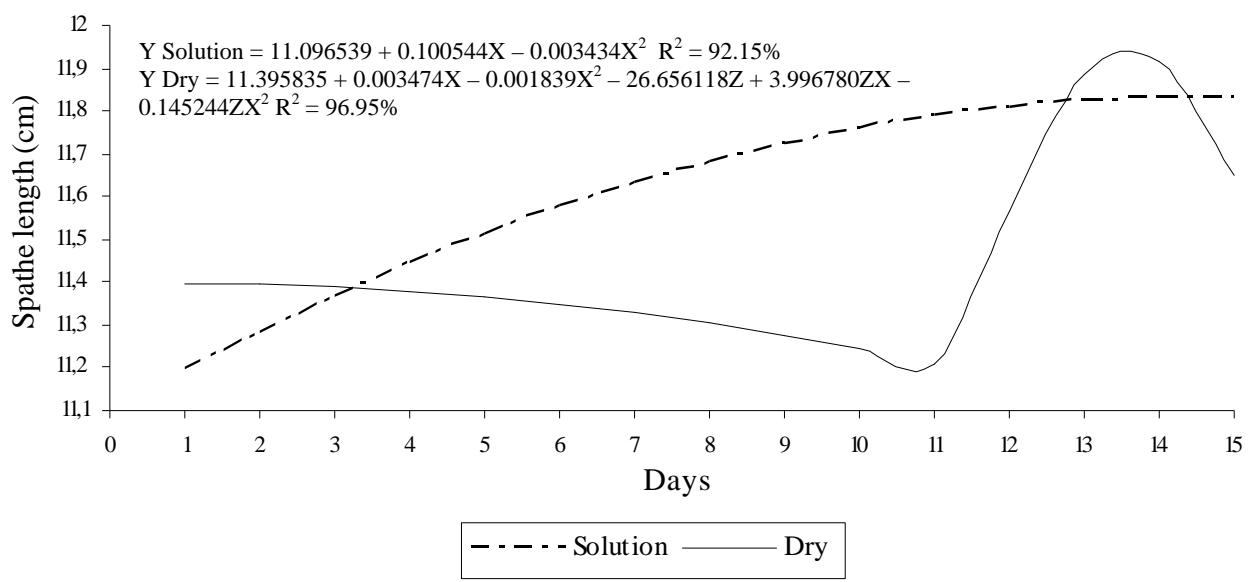

Figure 7 - Calla lily inflorescence spathe length $(\mathrm{cm})$ as a function of the storage type. 1-10 days inflorescences maintained in cold chamber at $4^{\circ} \mathrm{C} ; 11-15$ days inflorescences maintained at room temperature.

\section{Discussion}

These results are accordance with Paulin (1986) who observed that the exogenous sugar supply delayed inflorescence senescence and the sucrose supply was efficient. For most species, sucrose is the main translocated sugar and, therefore, the form of carbon that most of the nonphotosynthesis tissues import, can be considered the main sugar substrate for plant restoration (TAIZ; ZEIGER, 1991).

The use of $12.25 \%$ sucrose concentration was the most efficient for the dry conservation system. The tissues probably required higher carbohydrate reserves to maintain their biochemical processes, which, consequently, increased inflorescence longevity (NOWAK; RUDNICK, 1990). The lower concentration (5.23\%) was satisfactory for the inflorescences maintained in solution since a continuous water and carbohydrate supply was available with the maintenance solution.

This result indicated that calla lily inflorescences can be stored in a cool environment, without preservative solution or water. According to Nowak e Rudnicki (1990), some species present a longer conservation period, with desirable quality standards, when they are stored dry. The dry storage system has the advantages of occupying less space inside the cold chamber and is more practical for producers, wholesalers and retailers and for transport in refrigerated trucks, once there is no need for frequent solution change. Furthermore, the flower stalks can be placed on shelves inside the cold chamber or in refrigerated truck for calla lily dry storage and inflorescence transport.

The absence of splits in the base of the flower stalk, resulting from the prior-treatment with sucrose at the higher concentrations is desirable. The aspect present by the flower stalks, with split bases, limits the quality of calla lily inflorescences and it is difficult to fix in arrangements. Furthermore, the exposed area of the flower stalk base is large which facilitates microorganism development.

According to Kofranek e Halevy (1976), suitable sucrose concentration for extending inflorescence durability depends on the species. The results observed in calla lily show that in addition to the used species, flower management after supplying exogenous sugar was also important in determining the most adequate concentration to maintain inflorescence quality.

Reduction in spathe width indicates that the edges had wilted. This characteristic associated to the occurrence of necrosis indicates inflorescence senescence (TJIA; FUNNELL, 1986). Thus it is desirable that the spathe increases slowly in width so that it remains as many days as possible in the expansion stage, which was possible using pulsing with $7.36 \%$ sucrose solution (spathe width) (Figure 6) and 7.68\% (spathe length). The results indicate that pulsing with $7.5 \%$ average sucrose solution before storage, may be used to delay wilting in calla lily inflorescences placed in solution, indicating higher durability.

The inflorescences that recovered turgidity after water supply presented no commercial quality due to the occurrence of necrosis. It was concluded that the period for calla lily inflorescence dry storage should not be as long as the storage period for inflorescences placed in solution. During dry storage for a shorter period (up to six days), the inflorescences presented wilting but recovered turgidity quickly when placed in water, presenting quality for commercialization. 


\section{CONCLUSIONS}

The use of pulsing with 5 or $7.5 \%$ sucrose is recommended for cold storage in solution and $12 \%$ sucrose for dry storage.

Dry storage for calla lily inflorescences can be performed, only for short periods. The recommended period is up to six days, as long as a prior-treatment with sucrose at concentrations higher than $2 \%$ or with pure water for one hour before placing the flower stalks in a cold chamber are used.

\section{REFERENCES}

ALMEIDA, E.F.A.; PAIVA, P.D.de O. Cultivo de copode-leite. Informe Agropecuário, Belo Horizonte, v.26, n.227, p.30-35, mar./abr. 2005.

ALMEIDA, E.F.A. et al. Pós-colheita de copo-de-leite: efeito de diferentes conservantes comerciais e armazenamento a frio. Ciência e Agrotecnologia, Lavras, v.32, n.4, p.1189-1194, jul./ago. 2008.

BARBOSA, J.G. et al. Longevidade de inflorescências de lírio, de diferentes estádios de colheita, pré-tratadas com sacarose e tiossulfato de prata (STS). Ciência Rural, n.1, v.36, p.99-104, jan./fev. 2006.

FINGER, F.L. Pulsing with sucrose and silver thiosulfate extend the vase life of Consolida ajacis. Acta Horticulturae, v.543, p.63-67, 2001.
HALEVY, A.H.; KOHL, H.C.; KOFRANEK, A.M. Senescence and postharvest handling of Cyclamen Flowers. HortScience, v.19, p.848-850, 1984.

KOFRANEK, A.M.; HALEVY, A.H. Sucrose pulsing of gladiolus stems before storage to increase spike quality. HortScience, v.11, p.572-573, 1976.

MARISSEN, N. Effects of pre-harvest light intensity and temperature on carbohydrate levels and vase life of cut roses. Acta Horticulturae, v.543, p.331-335, 2001.

\section{NOWAK, J.; RUDNICKI, R.M. Postharvest handling and storage of cut flowers, florist greens and potted plants. Portland: Timber Press, 1990, $210 \mathrm{p}$.}

PAULIN, A. Influence of exogenous sugars on the evolution of some senescence petals. Acta Hortiulturae, v.181, p.183-194, 1986.

TAIZ, L.; ZEIGER, E. Plant Physiology. California: The Benjamin / Cummings, California, 1991, 565p.

TJIA, B. O.; FUNNELL, K. A. Postharvest studies of Zantedeschia inflorescences. Acta Horticulturae, Amsterdam, v. 181, p. 451-458, 1986. 